\title{
Development Issues and Potential Safeguards: A Study on Bangladesh Stock Market
}

\section{Md. Toufique Hossain}

Lecturer, Department of Business Administration, European University of Bangladesh, Dhaka, BANGLADESH

*Corresponding Contact:

Email: toufique2010@gmail.com

Mobile: +880179700327

\begin{abstract}
The capital market is a very prankish place that holds two types of risk. One is the risk at the efficiency level of the market that refers to the structural weakness. And the other one is the man-made danger that indicates the stakeholders' irrational behaviors some examples of which are manipulation, gambling, speculation, rumor and so on. Out of the two, the structural weakness is a sensitive issue of the market, and it can be abated at a great extend when the market is properly structured. Here, the author has mentioned five shields which are termed as the "Financial Safeguards" symbolically. Those are adapting Corporate Governance, introducing Financial Reporting Act, making stock market tribunal, exploring product diversification and enhancing the investors' knowledge. The complete implementation of these safeguards is absent in Bangladeshi market though they leave a little impact. This article examines those points and how they can be effective rooting the existing problems out from the market.
\end{abstract}

Key Words: Financial Safeguards, Corporate Governance, Financial Reporting Act, Special Tribunal JEL Classification code: D53, G1, G3

\section{INTRODUCTION}

An exclusive CPD research also showed that Bangladesh's capital market has been contaminated by 'toxic' elements in all three areas, i.e. primary market and secondary market and regarding their linkage with money market.

Although the SEC as a regulatory body bears the primary responsibility for failing to contain the toxicity in the capital market, weaknesses in enforcing financial discipline is also indicative of a lack of oversight on the part of the Bangladesh Bank and the Ministry of Finance. The coordination between different segments of the financial sector (i.e. money market, capital market and bond market) was not maintained as they should have been during the last few years, for example, refers to 2009 from 2012. Moreover, the interlink ages of fraudulent activities in different areas of the capital market, in the end, affected the overall operations of the market and made the market 'dysfunctional' to a large extent (CPD, 2011). 
Development of a stock market depends on implementing a better structural framework inside the market as safeguards against the market vulnerability. These days, the financial assurance is the most promising approach to reduce the vulnerability of the capital market.

In Bangladesh, there is lacking of knowledge of our stock investors exceptionally known as small investors. Therefore, if the regulators of the market ensure proper safeguards inside the stock market, then it will be better not only for the institutional investors but also for the small investors. The initial goal that a stock marker focuses on is to serve as a mechanism for transformation of savings into financing for the real sector. But investments in the stock market involve some risks.

Hossain (2014) finds that the stock market in Bangladesh is a frontier market in nature. It is easy to derive any undue benefit from such a small market by manipulating things. So, what we need is to rise above greed and fear and let the market function as per its fundamentals.

If the stock market, especially the Dhaka Stock Exchange (DSE), is compared with international markets considering their general price index, PE ratio, market capitalization, total trading value and market capitalization-to-GDP ratio, we see more fluctuations in the DSE indicators than those in the overseas markets. During the period from 2009 to 2012 extreme ups and downs happened because of the structural weakness.

The stock market will not be stable if the sectors involved with it are not stable. So, much depends on the sustainability of the related financial fields like mutual funds, insurance companies, merchant banks, bond markets, banks, etc. Many think the stock market crashes in 1996 and 2010-11 happened mainly due to the structural weaknesses. So, fruitful financial safeguards like corporate governance, adoption of a Financial Reporting Act and a special tribunal for the market should be made effective as early as possible. There also should be a technical setup to analyze the causes of a market crash.

Moreover, the progress and prosperity of Capital Market depend on the best use of financial safeguards. The stock market has to abide by some rules and regulations. Without potential market instruments, there is no stability and sustainable development.

\section{RATIONALE FOR THE STUdY}

Financial protections are very relevant and critical issue in the prospect of Bangladesh Capital market. Bangladesh Stock market already experienced two massive debacles respectively in 1996 and 2010-11. In Bangladesh, both the mishaps occurred because of the lack of good governance, financial reporting and an absence of financial market tribunal. A safeguard reduces financial market vulnerability.

A safeguard reduces financial market vulnerability, especially in a stock risk. The little analysis about the financial safeguards in the prospect of the stock market in the developed countries. So, the present study will help us to describe the concept of implementing financial shields in the prospect of Bangladesh stock market as an obliging reference for the students, researchers, academicians and policymakers of the Capital market.

These safeguards are necessary for a vibrant stock market but further researches are required on whether only these will be enough, or anything else should come since this is a new-born idea (The Author). 


\section{LITERATURE REVIEW}

Very few studies have been conducted regarding the stock market safeguards. Majority numbers of the studies aim at finding out how financial safeguards prevent financial malpractices in the financial market.

Schinasi (2006), in his book "safeguarding financial stability: theory and practice" made and attempted to identify in part two (I) developing an inclusive and pragmatic framework for ensuring financial stability encompassing the preclusion and at the same time, the answer to financial imbalances, problems, and crises. He also tried to evaluate several things in his book. He says that the pace of financial systems expansion was higher than that of the real economy. A multiplex of yearly economic production is limned through complete financial assets in matured economies. Also adds that the financial system is now more complex regarding the complication of financial instruments, the compeer risk mobility, and the diversity of activities. Moreover, liberalization and deregulation strengthened the adjustability of risks.

Hasan, Hossain and Swierenga (2013) in their article "Corporate Governance and Financial Disclosures: Bangladesh" wanted to analyze the influence of corporate governance on financial reporting disclosures. Their study shows an association between corporate governance and the extent of financial reporting disclosures. External auditor, multi-listing and profitability are significantly five percent associated with overall financial reporting disclosures index. Further, their article emphasized that the external auditor, a corporate governance variable, can influence the level of corporate financial disclosures. Other variables, such as board independence, board-size, dominant personality, institutional ownership and the general public are not effectively linked with the stage of financial disclosures. As such, the corporate governance structure in Bangladesh is not at the acceptable level.

Sohel ( 2013) in his article "Tribunal for stock related cases takes off soon" stressed the fact that the listed companies or the manipulators, disregarding the aptitude always challenge the orders or the punishment, whenever the securities regulator inflict any fines on them. Indeed, he argues for setting up a special tribunal to bring back the investors' confidence in the stock market. AS the BSEC shows, the companies, investors and manipulators experienced more than 400 cases between 1996 and January this year. The recent stock market debacles in 2010-11 ensouled the government setting up a special tribunal to operate the stock market-related cases.

Ahmed (2015) in his article "Reform and policy support for capital market" argues that financial reporting act is one of the essential factors for Capital market betterment. He said about the desired and sought reform which is to the improvement in the financial reporting by the auditors. The government, though late, had given the word of passing the act named the Financial Reporting Act (FRA) under which a Financial Reporting Council (FRC) would operate as a watchdog in the auditing industry. Unfortunately, the government was to face the opposition.

Hossain (2015) in his article "BICM: Building a knowledge centre" made an attempt to say the importance of stock market education for stakeholders for sustainable development of Stock market. The author said that the capital market, where ups and downs are very usual is a risky venture. Though such price fluctuation has little influence on the market, it turns into a storm when the market turmoil happens.

Avoiding any market crash depends on the structure and the risk management mechanisms as well as the education level of the investors. The USA, though a developed country, experienced the Great Depression in 1930, an outcome of the stock market crash in 1929. But they recuperated from it with their strong risk management tools the investors' matured knowledge. 
Bangladesh needs to throw the light on the capital market and to make sure that the risk management tools are there. The establishment of a capacity development is also required for stakeholders' long-term betterment.

\section{ObJectives OF THE Study}

The analysis of the study formulates through a notable review of the literature dealing with the meaning and significance of implementing of five financial safeguards for sustainable development. Therefore, the objectives of this piece are:

- To provide an insight of the financial safeguards against risks.

- To define and specify the five cornerstones of the financial safeguards.

- $\quad$ To suggest some forth- looking plans alongside financial safeguards.

\section{Methodology of the Study}

This study is a descriptive research. It uses secondary sources of data to analyze the financial safeguards and its implications. The secondary data sourced from various published materials including different books, journals, different dailies, magazines and working papers.

\section{FINANCIAL SAFEGUARDS AGAINST RISKS}

Another debacle in Bangladesh's stock market is no more an issue. It has become an inevitable reality. Despite inaugurating a new price index under a regulatory framework, the index did not work up to the expectation. Moreover, instability has become the common characteristics of the stock market. Many think the stock market crashes in 1996 and 2010-11 happened mainly due to the structural weaknesses. So, obviously, we need a financial safeguard for a capital market that follows discipline well. A benign safeguard framework is worthy of capital market development. Some financial safeguards help to reduce the risks by addressing uncertainty about the stock market and ensuring proper discipline. Those are corporate governance, Introduction of Financial Reporting Act and making a legal framework such as the formation of a special tribunal for the stock exchanges, Educational institution for the stock market and diversification of various stock instruments.

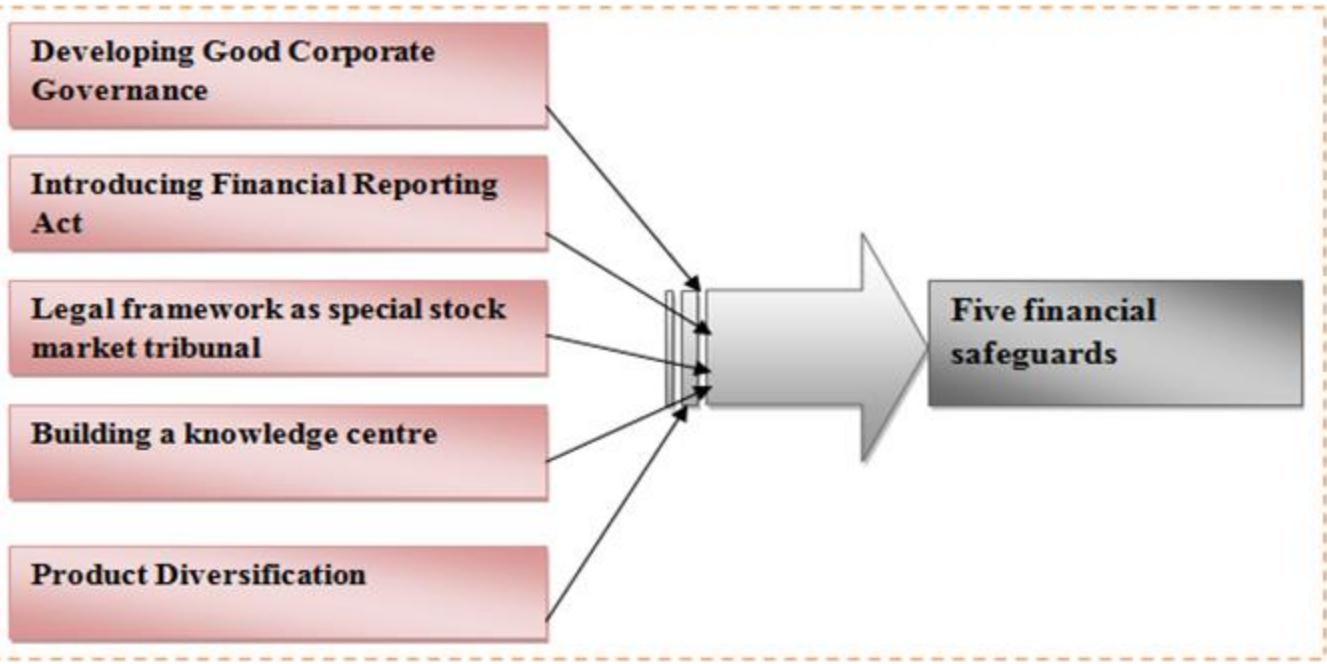

Figure 1: A Conceptual framework of financial safeguards

Source: Author Construct from relevant information 
In this figure 1, we see these five cornerstones of the financial safeguards. The five safeguards ensure three things: (1) market discipline and proper regulation; (2) strengthening the capital market against financial fraud; (3) implementing necessary safety instruments to ensure order and market survivability. Now, here we'll take a look at how the three safeguards work-

Now, have a look on major reforms of the Dhaka stock exchange those have been recently taken after the debacles of 2010-11.

Table 1: the major events of Dhaka Stock Exchange (DSE)

\begin{tabular}{|l|l|}
\hline Major Events of DSE & Effective date \\
\hline 1.Web-Based Trading Software-MSA Plus introduced & 10 June 2012 \\
\hline 2. Starting DSE broad Index (DSEX) \& DSE30 Index DS30(by S\&P) & 28 January 2013 \\
\hline 3. Bengali Website introduced & 18 February 2013 \\
\hline $\begin{array}{l}\text { 4. The Exchange Demutualization Act 2013 passed by the } \\
\text { Parliament }\end{array}$ & $\begin{array}{l}\text { 29 April } 2013 \text { (Effective } \\
\text { Date : 2 May 2013) }\end{array}$ \\
\hline 5. Introducing Shariah Index for DSE & 26 September 2013 \\
\hline 6. Introducing instant watch Market Surveillance Software & 11 February 2014 \\
\hline $\begin{array}{l}\text { 7. DSE has entered into an agreement with NASDAQ OMX and Flex } \\
\text { Trade Systems to provide the world progressive trading system }\end{array}$ & 21 March 2014 \\
\hline 8. Inauguration of Ultra-modern Trading System at DSE & 11 December 2014 \\
\hline
\end{tabular}

Source: DSE monthly review, year-end special Edition, December, 2014

Table 1 shows some strategies for stock market development. The Bangladesh Securities and Exchange Commission is set to conduct an assessment in the next two years to identify and address the underlying threats in the capital market. The assessment will look into market volatility and risk factors of intermediary players such as bourses, stockbrokers, stock dealers, merchant banks and asset management companies. After defining and classifying the vulnerabilities, the stock market regulators will develop a strategy to deal with the problems.

Chowdhury (2015) recognized that, "the stock market regulator has already started work on the 14-point plans include: setting up a clearing corporation for trade settlement of shares on the same day by 2016, a commodity exchange by 2017 and regulatory framework for derivative products by $2015^{\prime \prime}$.

\section{Corporate Governance}

Corporate governance includes the forms and procedures that relate to the control of companies and the rapport among the shareholders, stakeholders, the management and Board of Directors. It's such a regulatory and efficient approach that ensures proper disciplinary framework inside the capital market.

The history of corporate governance is very primeval and significant. The historical stock market crash happened in 1929 popularly known as Black Thursday/ Wall Street crash. After that, three scholars--Adolf Augustus Berle, Edwin Dodd, and Gardiner C. Means examined and reviewed and then developed the role of the modern corporation in society. It is assumed corporate governance emerged over that.

Practicing and implementing good corporate governance is a priority. Does good corporate governance promote better performance in the capital market? The obvious answer is 'yes'. Superior corporate governance is a key to the better capital market performance of listed companies trading on the stock exchanges in Bangladesh. 


\section{Impact of bad corporate governance}

The excessive manipulations in 1996 and 2010-11 hindered the Bangladesh capital market. Those were the outcomes of price- sensitive information, wrong asset valuation by listed companies and so on. It occurred because of weak corporate governance. Apart from these, there are other corporate governance problems like an absence of transparency and viability of listed companies' activities inside the market. For instance, a fraudulent company's insiders can access valuable information that can affect its stock price or might influence investor's decisions. In this case, ethics matters in the capital market's day-to-day management. So, the morals should be ensured through drawing a structured framework of corporate governance.

\section{Corporate governance framework}

Lack of good governance is the biggest obstacle to the effectiveness of Bangladesh's capital market. Four things as shown in the model below must be implemented to ensure corporate governance. Firstly, to secure the role of listed companies' directors as an independent body to supervise the management. In this case, some training workshops can be arranged for prospective administrators. It is also important to ensure a flow of corporate responsibility and reporting among management, Board, and stakeholders. Secondly, transparency and accountability are essential in case of efficient use of resources.

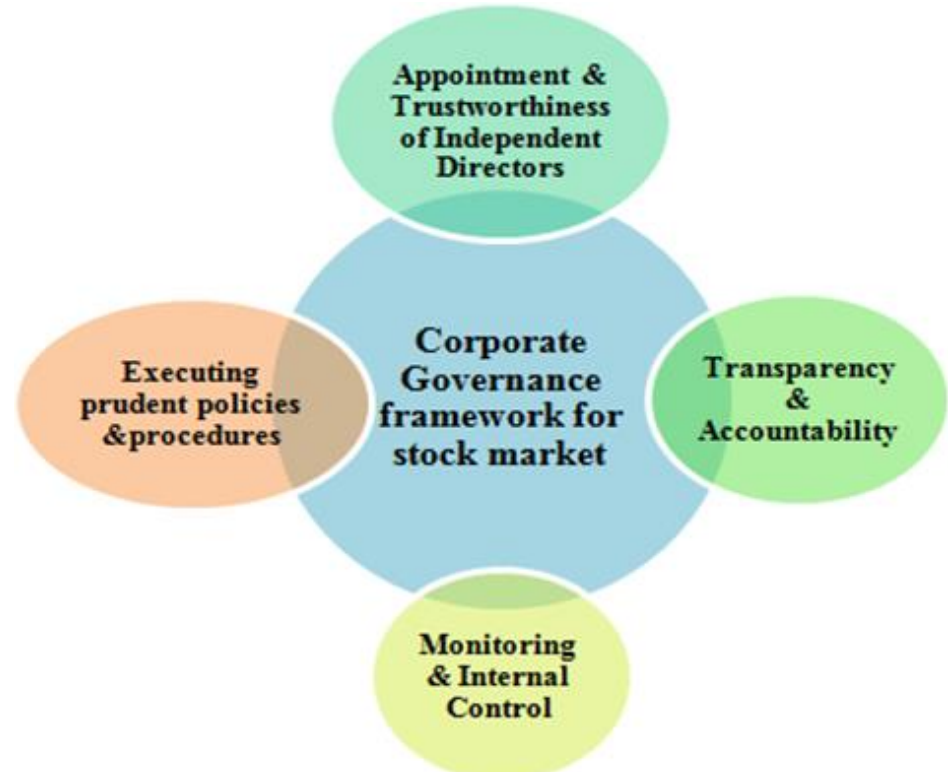

Figure 2: A Corporate Governance (CG) framework Source: Author Construct

The mentioned framework, though an assumption-based one, can be a model for the listed companies those have the corporate management.

Furthermore, monitoring and internal control help to mitigate any types of market abuses and manipulations. Besides, executing policies and procedures help to make the efficient guideline for market discipline. Again, a risk and management unit can help monitoring a trading environment, index movement and so on. 
Finally, a framework of corporate governance contributes to the sustainable economic development of a capital market by enhancing the performance of companies and helps to create investors' confidence.

\section{FinANCIAL REPORTING ACT}

The mandatory adoption of a Financial Reporting Act (FRA) influences the flow of company-specific information, and an accurate financial report contributes a lot. The financial reporting act is such mechanisms that create a special council namely "Financial Reporting Council (FRC)" will be formed if the act is passed. FRC consist of the expert professionals with proper subject knowledge.

The fraud audit practices are now being shown as one of the prime reasons for the recent stock market crash in Bangladesh. To say more specifically, the auditors, with the help of the management, produced inauthentic reports. As there are not many proofs, it is that it has. The blames are thrown to auditor is not the prime concern of this article. Since there were no Financial Acts in the country until the Act passed in 2015, no wonder the financial reports were flawed with a loophole.

\section{SPECIAL TRIBUnAL}

The Special Tribunal is the governing body concerning different types of investment securities and certain financial and investment matters. The tribunal will be a lawful agency that is independent and specialized in financial and investment concerns, problems, and disputes.

The extreme level of market anomalies is one of the key reasons for the stock market debacles in 1996 and 2010-11 respectively. The manipulators always go scot-free. Sad but true, still there is no example of punishment in the stock exchanges in Bangladesh.

In this case, a special tribunal can be a good strategy to prevent stock market misconduct.

\section{Building a KnOWLedge Centre}

The centre for learning the pros and cons of the capital market is the BICM (Bangladesh Institute of Capital Market) which is the first institute that tries to increase the investors' knowledge. The initial objective that the government is targeted is to make adroit stock market professionals providing with the proper knowledge. The BICM, established in 2008, promotes the praiseworthy market professionals who will be eager to develop a career not only in the stock market but also in the investors training programs. It is the country's first institution adorned with all the IT facilities and digital library with almost 10,000 books as well as E-book advantages. The government has established it as a multidisciplinary capital market learning centre for the implementation of the vision 2021. The BCIM's prime purpose is to bridge the rife between the current and the required level of knowledge among the capital market participants (Hossain, 2015).

\section{DiverRIFICATION}

Diversification refers to a strategy that mitigates risk through dividing investments among the financial instruments. It includes (a) developing bond market; (b) introducing derivatives and commodity exchanges; (c) strengthening the Mutual funds and so on (Hossain, 2012). 


\section{SUMMARY OF FINDINGS}

All the financial safeguards are therefore crucial for providing the right mix of market and regulatory discipline in a stock exchange.

- Governments can support market diversification and investors awareness program.

- Governments and regulatory authorities should make special tribunal that limits the market distortion.

- The government, regulatory authorities and related ministry should work independently without any interference by the big players.

- A discipline committee, as well as technical committee, can be constituted comprising experts from international financial market consultancy firms and the BSEC, Chartered Accountants, Cost Accountant, Chartered financial analysts, and planners.

\section{CONCLUDING REMARKS}

The Capital market plays a significant role in the long-term economic development of a country. Research studies conducted worldwide indicate that there is a high degree of positive correlation between the size of the capital market measured regarding of market capitalization and the level of economic development. In a case of Bangladesh, the capital market's movement is not only crucial for economic development, but it is also essential in the context of maintaining social harmony and ensuring a healthy political atmosphere.

Since joining in May 2011, the present Bangladesh Securities and Exchange Commission (BSEC) have been laying emphasis on restoring investors' confidence, bringing stability back on the capital market and promoting its development. A 5-dimensional approach was followed in this regard. Those areas: Conducting awareness raising programs; $b$. Enacting and amending rules and regulations; c. Ensuring better governance; d. Adopting appropriate technology and; e. Arranging regular coordination meeting with the ministry, Bangladesh Bank, stock exchanges and relevant stakeholders. For the last several years, some reform programs were undertaken by the BSEC intending to bringing stability to the market and making Bangladesh's capital market the principal source of long-term financing of industrial and infrastructural projects (Hossain, 2015).

First of all, investors' education should get more concern as it is very crucial. Anyway, here may exist many other emphatic reasons those can make the investment decisions stiff. Proper investment decisions require genuine financial reporting. Auditors should test data, accounts, statements, records and performance of the company and file their own opinions. The management, in turn, should provide the investors with authentic information. Because of the intervention of the Board, the management reporting cannot present the real picture of the companies' activities, while the audit quality is, in many cases, far from the gratification. In such situations, sometimes the investment decisions by disclosures may be risky.

Though this problem is open to all, the government, probably due to the hegemony of different pressure groups, has proved to be inconclusive for several years. Proper corporate governance is also a vital requirement for originating reliable financial disclosures. In this field, we've just started, and much practice may take years to be established. (Siddiqi, 2015)

In conclusion, Bangladesh stock market has many potentialities. To tap the potentialities, the government needs to recruit the right person and put him in the right place. The stock market should be considered as a part of an economy to explore the potentialities. Now is the proper time, to put in place all the financial safeguards for consolidating the fundamental base of the stock market and ensuring transparency. 


\section{REFERENCES}

A Chowdhury, Sarwar. (2015) ."Regulator to evaluate risks in stock market". The Daily Star, March 8, 2015, Retrieved from http://www.thedailystar.net/regulator-to-evaluate-risks-in-stockmarket$\underline{14104}$

Ahmed, Abu. (2015). "Reform and policy support for capital market", The Daily Star. Retrieved from http:/ / www.thedailystar.net/supplements/24th-anniversary-the-daily-star-part-1/reform- andpolicy-support-capital-market-73281

DSE Monthly Review, Year-end Special Edition, December 2014, Vol 29, No, 12.

Hasan, Md. Shamimul., Hossain,Syed. Zabid., and Swierenga, Robert. J. (2013). “Corporate Governance and Financial Disclosures: Bangladesh Perspective". Research Journal of Finance and Accounting. Vol.4, No.1.

Hossain, M. Khairul. (2015) ."Capital market: Towards stability and transparency". The Daily Star. Retrieved from http://www.thedailystar.net/supplements/24th-anniversary-the-daily-star-part$1 /$ capital-market-towards-stability-and-transparency

Hossain, Md. Toufique. (2014). "Overcoming the greed and fear factors", The Financial Express.VOL 22 NO 28 REGD NO DA 1589, Retrieved from http://www.thefinancialexpressbd.com $/ 2014 / 12 / 07 / 69780$

Hossain, Md. Toufique. (2015). "BICM: Building a knowledge centre”, The Financial Express, February 21, 2015, VOL 22 NO 102 REGD NO DA 1589, Retrieved from http://www.thefinancialexpressbd.com $/ 2015 / 02 / 21 / 82097 /$ print

Siddiqi, Faruq Ahmad. (2015) . "Stocktaking of stock market", The Daily Star. Retrieved fromhttp://www.thedailystar.net/supplements/24th-anniversary-the-daily-star-part$\underline{1 / \text { stocktaking-stock-market-73280 }}$

Sohel, Kayes. (2013). "Tribunal for stock related cases takes off soon". Dhaka Tribune, Retrieved from http://www.dhakatribune.com/regulation/2013/nov/15/tribunal-stock-related- cases-takessoon

The Centre for Policy Dialogue (CPD, 2011). State of the Bangladesh Economy FY2010-11, Second Reading. 
Publish Online and Print Version Both

ISSN Online: 2307-9592 